Ольга Красницька, кандидат педагогічних наук Національний університет оборони України імені Івана Черняховського

ORCID ID 0000-0002-0417-3318

DOI: $10.33099 / 2617-1775 / 2020-01 / 191-202$

\title{
МЕТОДИКА ПІДГОТОВКИ ПУБЛІЧНОГО ВИСТУПУ
}

У статті обтрунтовано й розкрито зміст методики підготовки публічного виступу. Окреслено основні аспекти підготовки промови у прачях вітчизняних $i$ зарубіжних дослідників. Публічний виступ представлено як можливість самопрезентації, донесення до широкого загалу ідей, думок, поглядів та інтенційних намірів. Визначено й охарактеризовано тринадиять етапів підготовки публічного виступу: визначення теми виступу, характеристика аудиторії («малювання» ї̈ портрету), формулювання мети виступу, підбір аналітичного матеріалу, підготовка тексту промови, візуалізація промови, підготовка запитань-відповідей, тренування публічного виступу, підготовка зовнішнього вигляду й «чарівної валізи оратора», психологічне самоналаштування, перевірка себе - контрольний список "Фенікс», самоаналіз публічної промови, самопохвала.

Ключові слова: публічний виступ; промова; викладач; офріцер; військовий керівник; оратор; доповідач; аудиторія; слухач; етапи підготовки публічного виступу.

Постановка проблеми. Яку роль для сучасного викладача, офіцера, військового керівника відіграє уміння володіти словом, уміння говорити, уміння впливати на навколишніх? Чи можна на сьогодні обійтися без розвинених ораторських умінь? Сучасне інформаційне суспільство вимагає від людини, а тим більше фахівця, діяльність якого протікає в ланці взаємодії «людина-людина», уміння сприймати, обробляти й передавати великі об'єми інформації, уміння вести ефективну комунікацію, висловлювати свої думки, доносити їх до аудиторії, переконливо говорити як з одним співрозмовником, так і десятками, сотнями, уміння виступати перед публікою.

Викладач під час навчального заняття не лише викладає слухачам (курсантам, студентам) матеріал із підручників та посібників, а створює цікаву й захопливу подорож до океану знань, розкриває перед ними нові горизонти, веде їх у світ професійного розвитку та самовдосконалення. Читання тексту лекції за кафедрою $\epsilon$ неефективним. Сучасний викладач будує активну взаємодію з аудиторією, яка виступає не лише в ролі учнів, а й в ролі вчителя. Він іiі навчає, мотивує, надихає, спрямовує і водночас вчиться в неї. Кожне навчальне заняття, виступ на науковій конференції, семінарі, звіт тощо $\epsilon$ публічними виступами. Військовий керівник, офіцер, який виступає перед особовим складом, на нараді, оголошує наказ, доводить інформацію, ставить завдання, дає інтерв'ю - виступає публічно. Він має вміти чітко, зрозуміло, доступно й переконливо говорити. Тобто публічні виступи супроводжують викладача, військового керівника, офіцера щодня. Варто сказати, що вони $\epsilon$ ораторами, які мають щоденно досягати успіху для ефективного виконання 
освітніх і службових завдань, професійних обов'язків перед суспільством та державою. Чи потребує публічний виступ попередньої підготовки?

Аналіз останніх досліджень і публікацій. Часто говорять, що публічний виступ не вимагає підготовки, краще за все звучить імпровізація. Але чи насправді це так? Мігель де Сервантес зауважує: «Говорити, не думаючи, - те саме, що стріляти, не прицілюючись». Навіть кваліфікований снайпер не потрапить точно в ціль без попередньої підготовки й концентрації на мішені. Необдумана думка звучить невпевнено та непереконливо. Аргументи, підібрані за одну хвилину, можуть стати неефективними для певної аудиторії. В. Шейнов виокремлює дві умови переконливості виступу: 1) високий рівень культури, професіоналізму, мовлення оратора; 2) гарна підготовка до виступу [14, с. 230]. Як відомо, успішний експромт - підготовлений експромт. До будь-якого виступу, навчального заняття потрібно готуватися.

Питання підготовки публічного виступу розглядають більшість науковців, викладачів, які займаються риторикою та ораторським мистецтвом. Проте, чи всі аспекти враховані? С. Абрамович і М. Чікарькова виділяють такі етапи підготовки промови: вибір теми, складання плану, збирання матеріалу, запис промови, розмітка тексту знаками паритури, тренування [1]. Зі свого боку, Х. Леммерман визначає збір матеріалу, відбір матеріалу та його організацію, обдумування матеріалу (медитація, зв'язка деталей, коментування матеріалу), першу редакцію ключових слів (попередня редакція), стилістичне оформлення головної частини (тренування у словесному оформленні), формулювання вступу й висновку, загальний контроль, другу редакцію ключових слів (остаточна редакція), уявне освоєння amp, риторичне освоєння (спроба промови) [8].

Відомий дослідник мистецтва переконання В. Шейнов наголошує, що до виступу потрібно зібрати інформацію, скласти план, написати текст публічної промови, провести репетицію [14]. О. Олійник виокремлює такі етапи підготовки виступу: теоретичний (вибір, формулювання, аналіз теми виступу), стратегічний (визначення надзавдання виступу та формулювання логікокомпозиційного уявлення про виклад матеріалу, тобто підготовка тез i загального плану промови), аналітичний (розробка теми та ii аналіз, бібліографічний пошук, нагромадження й систематизація матеріалу, складання тексту), редакційний (логіко-композиційний аналіз тексту промови та його доопрацювання, стилістичний аналіз тексту, літературне шліфування), тактичний (безпосередня підготовка до виступу з орієнтацією на конкретну аудиторію) [9].

Дослідниця комунікативної майстерності М. Соснова серед основних етапів підготовки промови називає аналіз ситуації публічного виступу, підбір і класифікацію матеріалу, складання плану та написання конспекту виступу, створення тексту промови [12]. I. Підкуркова виділяє визначення теми, формулювання мети, складання плану, збирання матеріалу, систематизацію матеріалів, обмірковування та аналіз матеріалу, етап письмової фіксації тексту промови, репетицію [10]. Зі свого боку, В. Вандишев та О. Переломова, орієнтуючись на древньогрецький канон, виокремлюють інвенцію (визначення 
теми, характеристика аудиторії, вибір матеріалу для виступу), диспозицію (розміщення матеріалу й оформлення структури промови), меморію (запам'ятовування тексту) [3].

Дещо відрізняється підхід до підготовки виступу у О. Фесенко, яка пропонує звернути увагу на визначення мети промови, збір інформації про аудиторію, конструювання свого образу, визначення власної ролі, підготовку тексту виступу, вибудовування промови згідно із законами сприйняття, використання можливостей мовлення, організацію простору для виступу, налаштування на аудиторію [13]. Нам імпонують погляди 3. Куньч, Г. Городиловської, І. Шмілик, які вважають за необхідне під час підготовки виступу визначити його тему (інвенція), добрати матеріал, скласти план, розподілити зібраний матеріал у необхідній логічній послідовності (диспозиція), написати текст 3 урахуванням мовностилістичних засобів (елокуція), запам'ятати його (меморія), виголосити промову перед аудиторією (акція) [6].

Аналіз праць вищезазначених авторів, а також О. Баєвої, Л. Введенської, Л. Павлової, Л. Мацько, О. Мацько, П. Сопера [11], І. Томана та ін. показує, що серед основних етапів підготовки публічного виступу ритори виокремлюють визначення теми промови, формулювання мети, складання плану, підготовку тексту, тренування. На наше переконання, у полі зору оратора залишаються досить важливі аспекти, на які варто звернути увагу. Десятирічний досвід публічних виступів за різноманітною тематикою, напрямами й жанрами, трирічний досвід викладання риторики в Національному університеті оборони України імені Івана Черняховського, навчання офіцерів, військових керівників та викладачів ораторському мистецтву й красномовству дав змогу нам обгрунтувати методику підготовки публічного виступу.

Мета статті - обгрунтувати та розкрити зміст методики підготовки публічного виступу.

Методи дослідження: аналіз, синтез, порівняння і систематизація наукових джерел, проєктування.

Виклад основного матеріалу. Підготовка публічного виступу - запорука його успіху. Чим грунтовнішою вона буде, тим оратор почуватиметься впевненіше, говоритиме переконливіше, а виступ стане вагомішим для слухачів. Як зазначають С. Абрамович і М. Чікарькова, «...всяка освіченість, має таку загадкову властивість: чим більше людина знає чужих думок, тим самостійнішим стає іiі власне мислення, тим оригінальніша вона в поглядах, а значить - цікавіша для інших» [1, с. 139]. Тож високий професійний рівень викладача, офіцера, військового керівника - оратора, всеобізнаність із питань, що доносить до цільової аудиторії, дасть йому змогу досягнути власної мети та успіху.

Методика підготовки публічного виступу містить у собі тринадцять етапів, що розкривають основні кроки, які має зробити оратор до забезпечення результативності власного публічного мовлення. Він має пам'ятати, що слухачі не бачать процесу підготовки виступу, але насолоджуються, або навпаки, його результатом. Оратор не зможе вибачитися за свою непідготовленість, іншими 
словами - аудиторію навіть не цікавить, скільки часу він мав та скільки приклав зусиль. Слухачі хочуть отримати результат, на який сподіваються, заради якого прийшли на виступ і заради якого витрачають свій дорогоцінний час. Отже, нами було визначено наступні етапи підготовки публічного виступу.

Периий eman - визначення теми виступу. Обираючи тему виступу, оратор має врахувати такі аспекти: цікавість теми для нього та аудиторії, чіткість формулювання, конкретність, потрібність цієї проблематики слухачам, головна ідея промови, «ізюминка», що приверне увагу, обізнаність оратора, достатній рівень знань та вмінь із тематики виступу. Існує два варіанти, коли тему промови оратор обирає самостійно, або вона вже задана, і він може іï конкретизувати. Але інтерес слухача до неї формується задовго до виходу доповідача та іiі озвучення.

Другий етаn - характеристика аудиторії («малювання» їі портрету). Оратор має пам'ятати, що під час публічної промови головною є аудиторія, а не він. Викладач, офіцер, військовий керівник виступає для слухачів, а не для себе. Його результат - це результати слухачів. Для ефективного впливу на аудиторію та побудови продуктивної взаємодії з нею, досягнення мети виступу необхідно визначити, на кого оратор буде впливати, 3 ким спілкуватися, тобто намалювати iї портрет. Якщо слухачі зібралися в одній аудиторії, їх щось об'єднує, варто це з'ясувати. Оратор повинен поставити перед собою мінімум два запитання: 1) Яка аудиторія мене очікує? 2) Що ця аудиторія знає про предмет виступу? Якщо слухачі гарно обізнані з теми, то оратору потрібно поставити третє запитання: як зробити предмет, добре відомий аудиторії, новим і цікавим?

Tpemiŭ eman - формулювання мети виступу. Мета - це кінцевий результат, якого викладач, офіцер, військовий керівник прагне досягнути під час публічного виступу. Промова без цілі $є$ неефективною, на яку доповідач даремно витрачає час. Оратору рекомендуємо поставити перед собою запитання: якого ефекту він хоче досягнути у виступі? Можливо, справити враження, щоб слухачі змінили свою поведінку, сприйняли інформацію, виконали поставлене завдання, купили книгу, записалися на курс тощо. Варто також конкретизувати, про що аудиторія має дізнатися, або що саме повинна зробити, яких дій оратор чекає від неї, чому його дослухають до кінця. Від цього залежатиме підбір інформації, вибір аргументів, постановка запитань, відповіді на них. Мета має бути співзвучною з темою, розкривати головну ідею промови, відповідати критеріям (позитивне формулювання цілі, реалістичність, конкретність, досягнутість, вимірювальність, гнучкість, екологічність, всеохоплюваність).

Четвертий етап - підбір аналітичного матеріалу. Він охоплює аналіз літературних джерел (енциклопедичної, навчально-методичної, наукової, науково-популярної, художньої, публіцистичної літератури), статистичних даних, офіційних документів, особистого досвіду, інтерв'ю, бесід, відеороликів, фільмів, матеріалів Internet тощо. Історії, притчі, цитати варто виписувати, вони знадобляться для привернення уваги. Необхідно максимально зібрати потрібної інформації та проаналізувати іiі, зробити виписки, закладки, занотувати тези. 
П'ятий eman - підготовка тексту промови. На цьому етапі оратор складає структуру виступу, що містить вступну, основну й заключну частини, i пише власне текст промови. Будь-який виступ має бути структурованим, незважаючи на те, чи це лекція, розповідь, звіт, оголошення наказу, виступ на нараді, вітальне слово, чи презентація. Р. Кушнір пише: «... структура - наче кістяк, який можна обшити м'ясом (фактами, цифрами, інформацією) та обтягнути шкірою (мотивація, форма подачі)» [7, с. 40]. Оратору необхідно продумати, про що він буде говорити у вступній, основній і заключній частинах промови, оскільки кожна з них має свої завдання. Таким чином, складеться уявна картинка всього виступу.

Оратор самостійно обирає шлях підготовки тексту виступу залежно від професіоналізму, досвіду, індивідуальних особливостей, а саме: написати весь текст повністю, занотувати тези, підготувати презентацію в PowerPoint чи іншій програмі, не записувати текст промови. Кріс Андерсон пише «...на жаль, більшість незаписаних промов виливаються в напівсирі пояснення, помилкові висновки, відсутність ключових елементів і зайву інформацію» [2, с. 146]. Ми рекомендуємо писати весь текст повністю, щоб у процесі підготовки його можна було відредагувати, перевірити регламент, обміркувати, доопрацювати, додаючи або вилучаючи певні елементи, репліки, речення, вивчити. Написаний текст легко під час репетиції промови вкласти у відведений для неї час. Виступати перед аудиторією бажано вже без аркушів або маючи тези виступу чи презентацію. Таким чином, оратор залишить можливість для імпровізації.

На етапі підготовки тексту промови потрібно також продумати техніки привертання уваги аудиторії й гармонійно їх вписати в текст промови. Особливо це стосується історій, притч, анекдотів, байок, вправ. Вони мають бути взаємопов'язані з матеріалом виступу.

Шостий eman - візуалізація промови. Найкращий виступ - той, який можна слухати, дивитися, відчувати й аналізувати. Як відомо, людина сприймає інформацію за різними каналами - візуальним, аудіальним, кінестетичним, дигітальним. Незважаючи на те, що один із них переважає, інші теж розвинені. Тому варто під час промови впливати на всі канали сприйняття інформації. Оратору необхідно за можливістю візуалізувати матеріал, що подає. Він може зробити презентацію (слайди), показати відеоролик, фото, картинки, плакати тощо. Також підготувати роздаткові матеріали, використати дошку чи фліпчарт і на них записати основні положення, намалювати схему.

Сьомий eman - підготовка запитань-відповідей. Досить поширеною причиною високого рівня хвилювання перед виступом $є$ боязнь запитань слухачів. Проте, знаючи аудиторію та предмет промови, оратор має змогу передбачити близько 80 \% можливих запитань і підготувати відповіді на них. Якщо виявиться, що на деякі не зможе відповісти, то потрібно проконсультуватися 3 іншими фахівцями. Недаремно Вінстон Черчилль ретельно готувався до виступів і всі свої найвідоміші фрази придумував та відшліфовував заздалегідь. Відповіді на запитання аудиторії - це ще одна можливість для викладача, офіцера, військового керівника підтвердити компетентність (експертність) у запропонованій проблемі чи темі, довести свою 
думку, озвучити головну ідею, переконати слухачів, закріпити в їхній пам'яті основні положення виступу, спонукати до дій, досягнути поставленої мети.

Восьмий eman - тренування публічного виступу. Будь-яка промова потребує репетиції, лише написаного тексту недостатньо. Його потрібно правильно озвучити й донести до аудиторії. Навіть цікаву інформацію можна спотворити за умови неправильної подачі, а зовсім нецікавою завоювати увагу слухачів. Вінстон Черчилль читав свої майбутні виступи у ванні, перед дзеркалом, у ліжку, в аудиторії тощо. Відомий оратор завжди тренував по декілька разів промову до того, як виголосити іiі перед цільовою аудиторією. Викладач, офіцер, військовий керівник не $є$ виключенням. Не варто спокушатися ідеєю, якщо оратор знає, що саме збирається сказати, то так все i скаже.

Тренування виступу дає можливість запам'ятати текст промови; розставити акценти, наголоси, зробити мовлення різноманітним; відпрацювати техніку мовлення; внести корективи у промову, відредагувати текст; продумати засоби взаємодії з аудиторією, техніки управління іiі увагою; відпрацювати стиль мовлення, доречний у певній ситуації; зробити виступ ясним, зрозумілим, доступним і цікавим для аудиторії; подолати невпевненість та хвилювання; відпрацювати регламент виступу; визначити недоліки й усунути їх; прослідкувати за своєю невербальною поведінкою; подивитися на візуальний матеріал виступу з боку аудиторії.

П. Сопер порівнює ефект від тренування публічного виступу з діяльністю актора. Учений пише: «...усі відмічають безпосередність, із якою тримаються на сцені актори. Якщо б виступали любителі, то глядач не стримався, щоб у цьому разі сказати: «Такий-то грав дуже природньо...». Але глядач не бачив їх на першій репетиції. Актори пропрацьовують кожен рух, кожен рядок по тридцять разів, а деякі жести та репліки повторюють по шістдесят-сто разів» $[11$, c. 23]. Тож для яскравого й переконливого виголошення промови іï необхідно кілька разів прочитати, запам'ятати основні положення, розставити акценти. Під час тренування оратор має можливість записати виступ на диктофон, щоб прослухати та врахувати дефекти мовлення, або виголосити перед друзями чи рідними, які забезпечать зворотний зв’язок і підкажуть, на що потрібно звернути увагу, або записати промову на відеокамеру. У виступі не має бути двозначних понять, висловів, незрозумілих для аудиторії метафор, порівнянь, слів, звуків «е-е-е, ну» тощо. Обов'язково потрібно виголосити промову 3 візуальними засобами, наприклад, презентацією, щоб знати, де зупинитися, де поглянути на слайд. Це забирає час, а оратор повинен дотримуватися регламенту виступу.

Дев'ятий етап - підготовка зовнішнього вигляду й «чарівної валізи оратора». Зовнішній вигляд - це візитна картка оратора. Викладач, офіцер, військовий керівник тільки-но переступає поріг аудиторії чи кабінету, виходить за кафедру, слухачі вже звертають на нього увагу - як він виглядає, у що вдягнений, яку має зачіску, далі - як рухається, його міміку, жести, потім - як він говорить. Зовнішній вигляд надає аудиторії першу інформацію про оратора, його смаки, стиль, охайність, повагу до неї й до себе. 
«Чарівна валіза» - це кейс (валіза) оратора, який він має взяти із собою на виступ. Йому необхідно ретельно продумати, які речі знадобляться під час промови та для безпосередньої підготовки до неї. Залежно від індивідуальних потреб викладач, офіцер, військовий керівник самостійно складає «чарівну валізу». Водночас відзначимо обов'язкові ії елементи, а саме: 1) предмети, що знадобляться під час виступу - ручка, презентер, лазерна указка, ноутбук, кабель до проєктора, планшет, доповідь, чисті аркуші паперу, флешка, роздатковий матеріал, фото тощо; 2) речі, що допоможуть привести зовнішній вигляд впорядок - гребінець для волосся, засіб із догляду за взуттям, змінний одяг, косметика тощо; 3) інші речі - аптечка, пляшка води, носова хустинка, парасолька тощо.

Десятий етап - психологічне самоналаштування. Досить часто можна спостерігати, що викладач, офіцер, військовий керівник покладається на надію, що все складеться добре, потрібно виступити - виступлю. Р. Кушнір пише: «...не можна виходити на виступ зі Швейковою філософією, що як би там не було, а якось то буде, бо ще не так було, щоб якось та й не було» [7]. У такому разі насправді все буде погано. Психологічна установка відіграє дуже важливу роль. Оратор має налаштуватися на приємні події, враження, дати собі позитивну установку на виступ, візуалізувати його. Упевненість у собі найважливіша якість лідера. Викладач, офіцер, військовий керівник - лідер для аудиторії, приклад для наслідування. Почервоніння, спітніння, метушіння абсолютно зайві. Надмірний рівень хвилювання можна побороти, знайшовши індивідуальні ефективні техніки й методи. Серед них виокремимо дихальні вправи, застосування методів психічної саморегуляції (аутогенне, психом'язове, ідеомоторне тренування, вплив на зовнішні прояви стресу, десенсибілізація, самомасаж тощо), фізичне навантаження (наприклад, вправа присідання 50 разів), телефонний дзвінок людині, яка надихне на успіх, підбадьорить, або прийти за 15 хв. до виступу й поспілкуватися зі слухачами тощо.

Оратору рекомендуємо візуалізувати успішний виступ. Візуалізація ефективний метод психічної саморегуляції, що дає змогу, приклавши мінімум зусиль, досягнути успіху. Джон Кехо у книзі «Підсвідомості все підвладне» зазначає, що за допомогою неї можна створювати власну реальність і впливати на неї. «...Для візуалізації необхідно уявляти себе в ситуації, що ще не відбулася, зображуючи, як ви робите або маєте те, чого хочете, й успішно досягаєте бажаних результатів» [4, с. 21]. Тут же автор приводить приклади успішних людей, зокрема Арнольда Шварцнеггера, Кріс Полейн, Браяна Едвардса, які використовували у своїй практиці цей метод для досягнення високих результатів. Таким чином, відображаючи вдалий виступ, оратор дає собі позитивну установку. Потрібно вірити у свій успіх. Психіка віддзеркалює наші думки в діях.

Одинадцятий етап - перевірка себе - контрольний список «Фенікс». Центральне розвідувальне управління США розробило контрольний список запитань «Фенікс», що дає змогу агентам поглянути на розв'язання завдання під різними кутами зору. Нами було складено список запитань, відповіді на які 
допоможуть подивитися на підготовлений виступ із різних боків, пересвідчитися у власній підготовленості до промови, за необхідністю внести останні зміни. Отже, оратору варто відповісти на такі запитання:

- Для чого (чому) я виступаю?

- Що я очікую від виступу? Від аудиторії?

- Як я зрозумію, що промова була успішною?

- Чому мій виступ $є$ корисним для слухачів?

- Що я знаю, у чому впевнений (щодо виголошення промови)?

- Що для мене залишається невідомим?

- Чи залишилися нерозв'язані (суперечливі) проблеми або питання?

- За скільки часу я маю прийти на виступ, щоб усе підготувати?

- Чи потрібна мені допомога?

- Чи може виникнути неочікувана ситуація під час виступу (наприклад, погасне світло)? Чи маю я план «Б»?

- Чи зможу я використати метод імпровізації в разі потреби?

- Я Яалаштований на успіх? Я впевнений у собі?

Наступним кроком оратора $є$ власне публічний виступ перед аудиторією. Проте процес підготовки від одного до іншого виступу є безперервним, адже варто згадати про аналіз промови, що дає можливість вдосконалити наступний виступ.

Дванадцятий eman - самоаналіз публічної промови. Це крок до розвитку ораторських умінь, підготовки наступного кращого виступу. Самоаналіз виступу дає змогу відшукати свої переваги, їх удосконалити й користуватися ними, а також - недоліки, способи їх усунення та недопущення помилок у майбутньому. Таким чином, це безперервний процес підготовки й самовдосконалення оратора - один виступ змінюється іншим.

Серед критеріїв самоаналізу публічної промови виділяємо такі:

- Успішність виступу. Чи досягнули мети свого виступу? Наскільки він був успішним?

- Дотримання регламенту. Чи вклалися в регламент? Якщо ні, то чому?

- Актуальність теми для аудиторії.

- Повнота викладення матеріалу, його структурованість.

- Якість вступної, основної та заключної частин промови. Чи в кожній частині було досягнуто мети? Чи був матеріал зрозумілий для аудиторії? Чи прослідковувалася логіка його викладу? Чи був матеріал візуалізований (реалізація принципу наочності).

- Активність аудиторії. Чи були активними слухачі під час виступу? Чи вони використовували методи рефлексивного, нерефлексивного слухання? Чи задавали запитання?

- Увага аудиторії. Чи був матеріал цікавим слухачам? Які техніки управління увагою використано? Чи вдалося утримати увагу аудиторії протягом усього виступу? 
- Переконливість публічної промови. Що вразило слухачів під час виступу? Що спонукало до дій? Що запам'яталося?

- Невербальна поведінка оратора - використані засоби кінесики та проксеміки, відчуття свободи й комфортності під час виступу.

- Техніка мовлення, культура мовлення оратора. Як використовували голос? Чи управляли за допомогою нього увагою аудиторії? Чи було мовлення різнобарвним, милозвучним?

- Запитання до оратора. Скільки їх було задано, які саме, якість відповідей на них.

- Успішність іміпровізації.

- Переваги виступу.

- Недоліки виступу.

- Задоволення власним виступом.

- Побажання (поради) для самовдосконалення.

Tринадцятий eman - самохвала - ресурс для наступних виступів. Після ретельного аналізу власної промови оратору варто похвалити себе, мотивувати до дій. Якщо навіть виступ був невдалим, необхідно знайти, за що себе можна похвалити. Можливо, за те, що оратор гарно тримався перед аудиторією, відповів на задані запитання, дотримався регламенту, привернув у певний момент увагу слухачів, вдало використав анекдот тощо. Будь-який виступ навчає, допомагає розвивати вміння, формувати практичні навички.

Публічний виступ - це можливість. Можливість показати себе, заявити про себе, презентувати результати власної діяльності, роботи команди, групи, організації, університету, кафедри. Це можливість висловити свою думку, донести до широкого загалу власну ідею. Це можливість підписати мільйонний контракт, відстояти свою позицію, виграти конкурс. Це можливість стати відомим. Це можливість пізнання себе, розвитку, самовдосконалення. Це можливість змінити своє життя та життя інших. Це вірний шлях до успіху. Як ми бачимо, публічний виступ представляє для кожного 3 нас тисячі можливостей [5, с. 138].

Висновки та перспективи подальших досліджень. Викладач, офіцер, військовий керівник - це людина, яка здатна змінювати життя слухачів, $\epsilon$ прикладом для наслідування, лідером для аудиторії, взірцем моральності, успішності та власної ефективності. Виступаючи публічно оратор має можливість показати себе, змінити думки іншої людини, захистити честь свого підрозділу, освітлити шлях для слухача, спонукати його до змін і нових перемог у житті та професійній діяльності.

Підготовка публічного виступу - запорука його ефективності. Оратор самостійно обирає шлях - до успішної промови або до провалу. Нами запропоновано методику підготовки вдалого публічного виступу, що принесе позитивний результат, як оратору, так i слухачам. Основними етапами підготовки промови $є$ такі: визначення теми виступу, характеристика аудиторії («малювання» iї портрету), формулювання мети виступу, підбір аналітичного матеріалу, підготовка тексту промови, візуалізація промови, підготовка 
запитань-відповідей, тренування публічного виступу, підготовка зовнішнього вигляду й «чарівної валізи оратора», психологічне самоналаштування, перевірка себе - контрольний список «Фенікс», самоаналіз публічної промови, самопохвала.

Перспективами подальших досліджень є вивчення особливостей управління увагою аудиторії під час публічного виступу, лайф-аків, що дадуть змогу зробити виступ цікавим, неординарним, новим для слухачів і забезпечать досягнення успіху у взаємодії з ними.

\section{ЛIТЕРАТУРА}

1. Абрамович С. Д., Чікарькова М. Ю. Риторика : навч. посіб. Львів : Світ, 2001. 240 с.

2. Андерсон Кріс. Успішні виступи на TED. Рецепти найкращих спікерів. 2-ге вид. Київ : Наш формат, 2017. 256 с.

3. Вандишев В. М., Переломова О. С. Риторика у філософсько-комунікативному вимірі : підручник. Київ : Кондор-вид-во, 2017. 492 с.

4. Кехо Джон. Підсвідомості все підвладне. Харків : Клуб Сімейного Дозвілля, 2019. $175 \mathrm{c}$.

5. Красницька Ольга. Відчуття щастя в публічному виступі. Щастя та сучасне суспільство : зб. матеріалів міжнар. наук. конф. (Львів, 20-21 березня 2020 р.). Львів : СПОЛОМ, 2020. С. 137-139.

6. Куньч Зоряна, Городиловська Галина, Шмілик Ірина. Риторика : підручник. Львів : вид-во Львівської політехніки, 2016. 496 с.

7. Кушнір Р. О. Великий оратор або як говорити так, щоб Вам аплодували стоячи. Дрогобич : Коло, 2013. 258 с.

8. Леммерман X. Учебник риторики. Тренировка речи с упражнениями. 2000. URL: https://royallib.com/read/lemmerman_X/uchebnik_ritoriki_trenirovka_rechi_s_upragneni yami.html\#122880.

9. Олійник О. Б. Основи ораторської майстерності : навч. посіб. Київ : Кондор, 2010. $181 \mathrm{c}$.

10. Ораторське мистецтво : підручник / М. П. Требін та ін. ; за ред. М. П. Требіна, Г. П. Клімової. 2-ге вид. Харків : Право, 2015. 208 с.

11. Сопер Поль Л. Основы искусства речи. Ростов-на-Дону : Феникс, 1995. 448 с.

12. Соснова М. Л. Тренинг коммуникативного мастерства : учеб.-практ. пособ. Москва : Академический Проект, 2010. 265 с.

13. Фесенко О. П. Академическая риторика : учеб пособ. Омск : изд-во АНО ВПО «Омский экономический институт»; ОАБИИ, 2015. 329 с.

14. Шейнов В. П. Искусство убеждать. Москва : ПРИОР, 2000. 304 с.

\section{REFERENCES}

1. Abramovych S. D., Chikarkova M. Yu. (2001) Rytoryka [Rhetoric] : navch. posib. Lviv : Svit. $240 \mathrm{~s}$.

2. Anderson Kris (2017) Uspishni vystupy na TED. Retsepty naikrashchykh spikeriv [Successful presentations at TED. Recipes of the best speakers]. 2-he vyd. Kyiv : Nash format. 256 s.

3. Vandyshev V. M., Perelomova O. S. (2017) Rytoryka u filosofsko-komunikatyvnomu vymiri [Rhetoric in philosophic-communicative dimension] : pidruchnyk. Kyiv : Kondor-vyd-vo. $492 \mathrm{~s}$.

4. Kekho Dzhon (2019) Pidsvidomosti vse pidvladne [Everything is a subject to subconsciousness]. Kharkiv : Klub Simeinoho Dozvillia. 175 s. 
5. Krasnytska Olha (2020) Vidchuttia shchastia v publichnomu vystupi [Perception of happiness in a public speech]. Shchastia ta suchasne suspilstvo : zb. materialiv mizhnar. nauk. konf. (Lviv, 20-21 bereznia 2020 r.). Lviv : SPOLOM. S. 137-139.

6. Kunch Zoriana, Horodylovska Halyna, Shmilyk Iryna (2016) Rytoryka [Rhetoric] : pidruchnyk. Lviv : vyd-vo Lvivskoi politekhniky. $496 \mathrm{~s}$.

7. Kushnir R. O. (2013) Velykyi orator abo yak hovoryty tak, shchob Vam aploduvaly stoiachy [Great orator or how to speak to receive standing applause]. Drohobych : Kolo. $258 \mathrm{~s}$.

8. Lemmerman X. (2000) Uchebnyk rytoryky. Trenyrovka rechy s uprazhnenyiamy [Manual of rhetoric. Training of speech with tasks]. URL: https://royallib.com/read/ lemmerman_X/uchebnik_ritoriki_trenirovka_rechi_s_upragneni yami.html\#122880.

9. Oliinyk O. B. (2010) Osnovy oratorskoi maisternosti [Basics of the mastery of oration] : navch. posib. Kyiv : Kondor. $181 \mathrm{s.}$

10. Oratorske mystetstvo [Public Speaking] : pidruchnyk (2015) / M. P. Trebin ta in. ; za red. M. P. Trebina, H. P. Klimovoi. 2-he vyd. Kharkiv : Pravo. 208 s.

11. Soper Pol L. (1995) Osnovy yskusstva rechy [Basis of the art of speech]. Rostov-naDonu : Fenyks. $448 \mathrm{~s}$.

12. Sosnova M. L. (2010) Trenynh kommunykatyvnoho masterstva [Training of mastery of communication] : ucheb.-prakt. posob. Moskva : Akademycheskyi Proekt. 265 s.

13. Fesenko O. P. (2015) Akademycheskaia rytoryka [Academic rhetoric] : ucheb posob. Omsk : yzd-vo ANO VPO «Omskyi ekonomycheskyi ynstytut»; OABYY. 329 s.

14. Sheinov V. P. (2000) Yskusstvo ubezhdat [Art of convincing]. Moskva : PRYOR. 304 s.

\section{PЕЗЮМЕ}

Ольга Красницкая, кандидат педагогических наук Национальный университет обороны Украины имени Ивана Черняховского

\section{Методика подготовки публичного выступления}

В статье обосновано и раскрыто содержание методики подготовки публичного выступления. Определены основные аспекты подготовки речи в трудах отечественных и зарубежных исследователей. Публичное выступление представлено как возможность самопрезентации, донесения до широкой общественности идей, мыслей, взглядов $и$ интенционных намерений. Определены и охарактеризованы тринадиать этапов подготовки публичного выступления: определение темы выступления, характеристика аудитории («рисование» ее портрета), формулировка иели выступления, подбор аналитического материала, подготовка текста речи, визуализация речи, подготовка вопросов-ответов, тренировка публичного выступления, подготовка внешнего вида и «волшебного чемодана оратора», психологическая самонастройка, проверка себя - контрольный список «Феникс», самоанализ публичной речи, самопохвала.

Ключевые слова: публичное выступление; речь; преподаватель; офицер; военный руководитель; оратор; докладчик; аудитория; слушатель; этапы подготовки публичного выступления.

\section{SUMMARY}

Olha Krasnytska

Candidate of Pedagogical Sciences, Ivan Cherniakhivsky National Defense University

\section{Methods of preparation of public presentation}


Introduction. Contemporary informational society requires from a person, and especially a specialist, whose activity runs in the chain of interaction "person-person", ability of comprehension, process and transfer of the large volumes of information, skills of effective communication, to express his or her thoughts, to bring them to the audience, to convince one, dozens or hundreds of interlocutors, skills of speaking on the public. A teacher during a class not only represents the contents of the manuals to the listeners, but creates interesting and breathtaking voyage to the ocean of knowledge, discloses them new horizons, leads them to the world of the professional development and self-improvement. Military head, officer, which speaks to the personnel at the meeting, reads out an order, transfers information, tasks, gives interview performs on public. I.e., public speeches follow a lecturer, military head, officer on the daily basis. Do they need preliminary training? Training is a guarantee of the effectiveness of a public speech. speech.

Purpose - to ground and disclose the content of the methods of preparation of a public

Methods: analysis, synthesis, comparison and systematization of the academic sources, projecting.

Results. It was grounded and disclosed the content of the methods of preparation of a public speech. There were outlined the main aspects of preparation of a speech in the works of the local and foreign researchers. The public speech was represented as an opportunity of selfrepresentation, transferring to the wide audience of ideas, thoughts, views and intentions. Were defined and characterized thirteen stages of preparation of a public speech: determining of a theme of a speech, characterization of an audience ("sketching" its portrait), formulating the aim of a speech, gathering the analytical data, preparation of a text of a speech, visualization of a speech, preparation $Q \& A$, training of a public speech, preparation of an appearance and a "magic suitcase of an orator", psychological self-adjusting, self-checking - checklist "Phoenix", self-analysis of a public speech, self-praising.

Originality. It was grounded and disclosed authoring methods of preparation of a public speech which contains thirteen stages - steps which have to be done by an orator before successful public presentation.

Conclusion. A lecturer, a military head is a person capable to change life of a listeners, who is an example for imitation, leader for an audience, example of morality, success and personal effectiveness. Making a presentation orator has an opportunity to represent his- or herself, to change mind of other person, to defend honor of his or her regiment, to shine out the way for a listener, to motivate him or her for changes and new victories in life and professional activity. Preparation of a public speech is the guarantee of its effectiveness. Orator independently chooses the way to a successful speech or to a failure. The proposed methods of a public speech, which will bring a positive result both to orator and audience, contains thirteen stages, aimed to achieving the successful result.

Key words: public speech; speech; teacher; officer; military head; orator; speaker; audience; listener; stages of preparation of a public speech. 